\title{
Veblen in Twenty-First Century America: The Renewal of a Critique
}

\author{
By John Stone* \\ Xiaoping $\mathrm{Luo}^{\dagger}$
}

\begin{abstract}
Thorstein Veblen (1857-1929), who was according to C. Wright Mills, "the best critic of America that America has produced", is particularly well known for his concepts of "conspicuous consumption", "invidious comparisons" and "trained incapacity". These ideas were first developed in his early classic The Theory of the Leisure Class (1899) as part of a devastating critique of consumption patterns during the era of the robber barons at the turn of the twentieth century. Veblen's assault on the assumptions of conventional economic theory, whose premises he found to be seriously lacking in plausibility, provided much insight into American financial capitalism leading up to the Great Depression in 1929. As inequality in the contemporary United States has increased significantly since the financial collapse in 2008, this article examines the explanations put forward by some current social scientists and compares them to Veblen's earlier ideas.
\end{abstract}

Keywords: Education, Inequality, Marginality, Technology and Warfare.

"They call it the American Dream because you have to be asleep to believe it."

George Carlin

\section{Inequality in America: Past and Present}

Even those who support neo-conservative economic policies do not deny that American society during the past three decades has become increasingly unequal. In itself this need not negate the American Dream ${ }^{1}$, the belief that anyone who works hard, develops entrepreneurial skills and will not be discouraged by short-term setbacks, can eventually join the affluent middle classes. Such a set of beliefs, deeply entwined with core American values of individualism, free enterprise and a highly restricted role for government, has been a dominant feature of American society for large parts of the $19^{\text {th }}$ and $20^{\text {th }}$ centuries. Provided that there is a constant flow of both upward and downward mobility it is still possible, in theory, to claim that the United States is a land of enormous opportunity. However, the sheer magnitude of the inequality in

\footnotetext{
* Professor, Boston University, USA.

$\dagger$ Associate Professor, Zhejiang Ocean University, China.

1 The idea of the American Dream has been re-described as "a split-screen American nightmare" by Robert Putnam in his latest book on contemporary inequality (2015:1). See also Stephen Mennell's assessment in his Eliasian perspective on American society (2007: 249265).
} 
contemporary America, already rivalling the patterns common during the "roaring twenties" can be found on so many dimensions: income, wealth, education and health, to mention just a few, that this revisionist version of the Dream has become increasingly implausible.

According to published income statistics, the CEO's of S \& P 500 firms received on average $\$ 12.3$ million in 2014 , a figure equal to 354 rank and file employees. The CEO- to-worker compensation ratio has increased steadily since the late 1980s: in 1978 the ratio was 30:1 and by 2013 it had risen to almost 300:1 (Economic Policy Institute 2014). Much the same trends can be seen in the "non- profit" sectors, hospital chief executives receiving around 125 times the income of lower paid workers; and the top ten private university presidents having annual base salaries of over a million dollars in 2012 (Strauss 2014). While such compensation in the last case is sometimes viewed as a just reward to exceptional individuals driven by market forces, particularly by the corporate Trustees of such institutions, it is hard to reconcile these figures with the compensation of the President of the United States $(\$ 400,000)$, a job for which there seems to be no shortage of candidates despite the comparatively low compensation. Whether the caliber of the candidates is that good is another matter, but the same could be said about university presidents.

However, income is only one measure of inequality in the United States and the full extent of financial disparities needs to include wealth in the equation. Here the divergences are even greater and because such wealth is easily transferred from one generation to the next, the development of an incipient caste system appears to be the current trajectory of American society. The traditional mechanisms of social mobility, particular the availability of low cost public education, have been successively eroded by rising tuition costs that make even those who can compete with the children of the privileged to gain access to institutions of higher learning arrive at a situation where they are then faced with a level of debt repayment on terms that are quite different from loans to business enterprises. Unlike insolvent businesses there is no provision for insolvent graduates to declare bankruptcy and move on.

If we look in more detail at changes in the differences in wealth some interesting patterns emerge. Data from a variety of sources show that overall wealth inequality has varied throughout the twentieth century, reaching a peak in 1928 when the top 0.1 percent of Americans controlled $24.8 \%$ of the total wealth. By 2012, this figure had returned to $22.0 \%$ but in the decades between 1940 and 1980 the levels of wealth inequality was reduced substantially reaching a low point of $7.1 \%$ in 1978 . A number of factors are generally given to account for the reversal of the trend towards greater equality after 1980 and these are linked to globalization, the decline of trade unions and the climate of neo-liberal economic strategies spearheaded by the Reagan-Thatcher political revolution (Kranish 2015, Piketty 2014: 199-270).

When it comes to inequality seen through the lens of racial and ethnic difference, these divisions become even more extreme. The studies of Oliver and Shapiro (1995) and Shapiro (2005) explain the racial wealth gap in terms of household income, huge differences in levels of inheritance and the 
historical legacy of slavery and Jim Crow. Since 2008, whatever gains that had been registered in narrowing the racial wealth gap were quickly eroded by the vulnerability of African Americans and other minorities to predatory lending practices and the central role of sub-prime mortgages in the collapse of the Stock Market. In a scenario that would not have surprised Veblen, it was the banks that were bailed out with taxpayers' money, while those who had recently acquired property were left subject to foreclosure and the loss of most if not all of the equity tied into their now bankrupt properties. This pattern was replicated all over America: a report by the Federal Reserve Bank of Boston, The Color of Wealth in Boston, (March 2015) reported "staggeringly divergent" levels of wealth by race (Woolhouse and Newsham 2015). Similar patterns have been found in other surveys in Los Angeles, Washington, Miami and Tulsa.

This important dimension of inequality was not the primary focus of Veblen's critique of American society in the 1920s, no doubt in part because the disparities in life chances within the dominant white community were exceptionally large and the marginalization of blacks and native Americans was so profound as for many observers, no matter how astute, to fail to see them as part of the same community. A century later, and with a black family living in the White House, the myth of a post-racial society would undoubtedly be seen as an integral problem of the same unjust economic system. Let us turn to this in greater detail.

\section{The Robber Barons and the One Percent}

Veblen's analysis of society in the first two decades of the twentieth century must be seen within the context of his diverse formative influences. His early graduate education in philosophy and the impact of the ideas of William Graham Sumner, a leading American proponent of social Darwinism and a disciple of Herbert Spencer, can be witnessed in his evolutionary approach to social change. Combining economics and sociology in a creative new direction, Veblen was able to steer both academic disciplines along a path that they had rarely considered before and one that was to result in two extremely fruitful fields: institutional economics and a new appreciation of the importance of consumption rather than a single minded obsession with production. Both areas raised provocative questions about the unreal assumptions of neo-classical economic theory as well as the manner in which economic behavior in the real world could rarely be understood in terms of conventional market relationships or simple-minded notions of utility maximization. While some of Veblen's ideas are products of his time and have long been discounted, several of his key concepts have proven to be seminal and have filtered into the social sciences as indispensable tools for understanding American life and society in the twentieth and twenty-first centuries. 
Veblen's notion of "conspicuous consumption" is without doubt the most famous of these and to appreciate the life-styles of the very wealthy in an era of incredible inequality, not to mention the impact of such behavior throughout the rest of society, is but one of his concepts that has been absorbed into modern everyday language. Along with Weber's ability to resolve the apparent paradox between the aesthetic Calvinist entrepreneurs of the early industrial revolution - the strange merging of other-worldly religiosity with an obsession for economic accumulation and the relentless pursuit of entrepreneurial success -- Veblen provides crucial insight into the mind set of those fixated with the desire to turn wealth into status. This he does by pointing to related activities in very different societies, the potlatch ceremonies of the Kwakiutl Indians where those who can burn the most of their possessions in public are considered to be the "wealthiest" in terms of prestige; or the foot-binding fashions of the Chinese merchant classes whose status is enhanced by demonstrating that they can afford to support wives who are sufficiently crippled that they can never undertake any useful work. Such anthropological insights help to place certain apparently irrational human activities in comparative perspective and show how they do, in fact, have an underlying logic of their own.

But Veblen's critique of the age of affluence is by no means confined to the leisure activities of the super-rich. His model of such an economy is linked to a division between two classes of economic actors: the one that adds to society's useful production and the other who serves a predatory function designed to feed off the wealth of the nation while adding nothing to the welfare of society. Here Veblen differentiates between business and industry, contrasting the pecuniary from the industrial types of employment, in a manner that eerily anticipates the current debates between Wall Street and Main Street. The former emphasizes the profit-maximizing activities of the speculative actors in the economic system in sharp contrast to the hard working industrial classes using new technology to improve economic performance. The pecuniary classes have no other aim or motivation than the maximization of profit which can as easily be achieved through restricting output, reducing competition and manipulating monopolistic power than contributing to the economic success of society. In this respect he differed from William Graham Sumner, his teacher at Yale, who considered the financiers and industrialists to be the "fittest" individuals in the economic arena, the epitome of modern civilization. Veblen argued that it was the technologists and scientists who were the genuine embodiment of progress. ${ }^{2}$ Most of the "captains of industry" - the infamous "robber barons" of the Gilded Age - were predators and parasites sabotaging the genuine growth in wealth and productivity. Machine

\footnotetext{
${ }^{2}$ Most contemporary scholars would have less faith in scientists and technicians standing up to the pressures of the entrepreneurial forces in modern corporate America. In fact, some studies have shown the need for a subtle alliance between technologists and business people to bring about successful technological innovation (Rizova 2007). Such a position reverts back to the Saint-Simonian notions of society being managed by industrialists and scientists and is very different from Veblen's vision of the two groups having totally contradictory goals.
} 
technology was the core element in modern society and it was the continued advancement of the "industrial arts and the machine process" that would result in evolutionary progress triumphing over the predatory practices of the pecuniary sector.

If we switch our attention from this scenario based on the first two decades of the twentieth century to the same decades a hundred years later, some interesting parallels emerge. One fascinating example is the growth of high frequency trading (HFT), employing complex algorithms and super computers to intervene in market transactions over fractions of a second, by buying and selling shares ahead of conventional traders (Lewis 2014). In this way, vast profits can be extracted from countless transactions without even the awareness of other traders and shareowners. This ingenious use of technology to exploit a miniscule time-lapse in the automated stock market, would clearly be defined in another context as illegal "insider trading" and it also makes a mockery of the assumption of "perfect knowledge" supposedly available to all market participants in neo-classical economic theory. No one could deny the effort and skill devoted to such tactics to profit from what has been increasingly described as "casino capitalism", but the problem from Veblen's standpoint is that this is a clear case where technology has been exploited to the full in order to benefit individuals who are making absolutely no contribution to enhancing productivity or developing needed goods or services. In the twenty-first century, it is becoming increasingly difficult to separate the scientists and technicians from the "captains of industry" that Veblen so savagely lampooned. In one of his most memorable comments he captures the spirit of the age: "In the beginning the captain of industry set out to do something, and in the end he sat down to do somebody" (Veblen 1923: 389).

Two other features of Veblen's economic model have been particularly important for our subsequent understanding of business organization and economic change. The first of these is the notion of the division of ownership and control in large scale business corporations. In theory, the shareholders of industrial enterprises are the ones that dictate policies to maximize the returns on their investments. In reality, it is the corporate hierarchy, those responsible for the day-to-day running of the operation that rapidly usurps much of the power to make decisions and can distort the strategies to fulfill their own goals. This insight into the development of the modern corporation was later developed in its seminal form by Adolf Berle and Gardiner Means in their 1932 classic The Modern Corporation and Private Property. Increasingly the systems of accountability of industrial organization have become gradually weaker and the organization's leaders, together with compliant and frequently overlapping memberships on Boards of Directors and Trustees, can explain why it is that even after demonstrable failures in management and performance the compensation of CEOs and other executives is often increased. Veblen's great contribution to the development of institutional economics, to the recognition, as Adam Smith did in The Theory of Moral Sentiments (1759) long before many economists had forgotten the social limitations of the "invisible hand", that markets are human constructs and must be viewed in 
their social settings, are contributions to understanding the limitations of certain strands of economic theory ${ }^{3}$.

Another fascinating insight from Veblen's economic perspective was derived from his study, Imperial Germany and the Industrial Revolution (1915) where he pointed to the unexpected advantages of being slow on the uptake in economic development. There were, in fact, as his comparison between the paths of industrialization in Britain and Germany revealed the distinct possibility of learning from the mistakes of others particularly when it came to the application of technology. Given Veblen's idealization of science and technology in the process of genuine economic progress it is hardly surprising that he noted this initially unexpected advantage of not being in the forefront of technological application. Once again, more modern examples of this process: Japan and Germany in the wake of the Second World War; and the industrial rise of China and India in the twenty first century, show some further applications of this insight. While India's lack of infrastructure for telephone communications was in part due to a difficult climate subject to Monsoon downpours and related floods, the rise of cell phones and satellite systems have rendered the lack of previously vital pre-conditions for economic development obsolete. Just as Veblen noted the advantages that Germany gained by using a wider gauge of rail tracks, compared to the narrower and increasingly restrictive capacity of the system pioneered by the British, so technological advances in communication have assisted the economies of East and South Asia to make rapid improvements in their industrial competitiveness.

\section{Education and the Fading American Dream}

A further element in Veblen's critique of America's social institutions rests with the field in which he was employed for much of his life. Apart from his idiosyncratic academic career, not enhanced by his outspoken lack of religious faith and his reputation as a philanderer, moving from the University of Chicago, then to Stanford and on to the University of Missouri in a steady spiral of personal decline and fall, Veblen continued his devastating criticism of the American University. In many ways it was an extension of his attack on the captains of industry as the sanitized sub-title of his book on the subject clearly reveals. The Higher Learning in America: A Memorandum on the Conduct of Universities by Business Men (1918). The original sub-title -- A Study in Utter Depravity -- had been removed at the insistence of the publishers and there is little doubt that the replacement provided a more precise description of the argument even if it failed to record the full extent of the author's contempt for those academic leaders whose major preoccupation was extracting "gifts for conspicuous buildings" (1918: 526).

\footnotetext{
${ }^{3}$ It is worth noting that in her valuable comparative analysis of economics and economists in the United States, Britain and France from the 1880s to the 1990s, Marion Fourcade (2009) makes absolutely no reference to Veblen or to the issues surrounding consumption.
} 
Certain aspects of Veblen's analysis still resonate with twenty-first century concerns about the governance and direction of the American Academy. Books like Benjamin Ginsberg's The Fall of the Faculty: The Rise of the AllAdministrative University and Why it Matters (2011) capture many of the same issues, even if the modern author is somewhat more Weberian than neoMarxist in his emphasis. Veblen does indeed focus his contempt on the "sturdy beggars" found among the permanent officials of the American Universities; the emphasis on committee work rather than scholarship or teaching (not that Veblen could claim any serious commitment to excellence in the latter activity); and the "mischief incident to 'scientific management' in academic affairs" (1918: 524). He noted how state universities were unduly dependent on the favours of local politicians, how administrators could not distinguish between "scholarship and publicity" and how the typical career path of academic executives produced a "quasi-literate leisure class" - the "captains of erudition" - marked by a tenacious and aggressive self-selection and displaying a "facile conformity" of "flunkeys waiting to move up" the administrative ladder. As for the American College President, such an office was deemed to be unnecessary, but without the removal of both the academic chief executive and the governing board such a transformation would fail "because the evils sought to be remedied are inherent in these organs and are intrinsic to their functioning" (1918: 538). In other words, it was a systemic failure and only the complete removal of the expensive and irrelevant academic administrative structure could return university governance to the faculty, the only people qualified to assume this role.

Other studies in the twenty first century have followed a similar line of attack against the bureaucratic takeover of the Universities and Colleges in America, providing empirical support for the continuing corporate goals of higher education. A report by the Institute for Policy Studies (Erwin and Wood 2014) demonstrated a relationship between the salaries of presidents and other types of expenditure. In state schools with the highest paid presidents the percentage of University administrative budgets rose much more rapidly than scholarships and there was a corresponding decline in the percentage of permanent faculty ${ }^{4}$. Increasingly, teaching has been outsourced to "adjunct faculty", either graduate students or recent $\mathrm{PhDs}$ unable to secure the diminishing number of tenure-track lines, who are paid low salaries, have little or no job security, and often are provided with no health coverage or pension rights. This pattern, reflecting the strategy of global corporations shifting higher paid jobs to lower paid alternatives, further strengthens the administrative grip on decision making: the growth in the number of nonacademic officials hired to run all the paraphernalia of the modern American University - Ginsberg's "deanlets" - and the ever-escalating cost of tuition, which has outpaced the rate of inflation over the past two decades. The outcome is a situation where the higher education system, built on and

\footnotetext{
${ }^{4}$ What seems to be the case for public universities is also true for private universities. See: Schworm 2014.
} 
accentuating the inequalities in schooling, rather than helping to facilitate social mobility, in fact stifles it.

In another example, where Veblen's trust in technology to mitigate some of the distortions of the price system doesn't seem to hold, the enthusiastic greeting of MOOCs - Massive Open On-line Courses - that appears to offer access to free, on-line courses often provided by instructors from elite universities. At first sight, this innovation in educational access seems to be an antidote to the escalating cost of those vital advanced educational qualifications needed to compete in the global economy. In practice, the ability of most people to substitute on-line free education for expensive conventional forms of higher education seems minimal (Rhoads 2015). As a direct result of the escalating costs of college education, the pattern of increasing inequality in income and wealth in society as a whole is merely repeated in the educational sphere. Higher education is reverting to be the prerogative of the rich, while most of the rest of society is relentlessly excluded from it, forced to take inferior substitutes, or are saddled with massive debts for much of the rest of their lives. Furthermore, one of the most valuable advantages of a formal university education is the contacts that are made in these formative years and how they open up opportunities for future careers. Mark Granovetter's demonstration of the "strength of weak ties" (1973) is never more accurate than in the power of elite college cohorts to help one another in the job market after graduation.

Another feature of the modern American University is the stress on fund raising to be undertaken by appointments at increasingly lower levels of the academic hierarchy. Qualities that are repeatedly stressed in advertisements for positions such as Deans and even Chairs of departments is a track record of successful fund raising. This is often seen as far more important than academic qualifications or teaching skills and explains the not infrequent choice of candidates with political or business connections as the "desirable" outcome of job searches for such positions. Increasingly such job selections are conducted by professional search firms ${ }^{5}$ who charge not insignificant amounts of money to draw on a small pool of candidates, many of whose identities are kept secret from the faculty on the grounds that an open search would embarrass them in their current positions should they not be selected. Furthermore, it is not uncommon for such candidates once selected to move on to other, better paid positions after a year or two and the whole process starts again. As Veblen might well have viewed this system as a continuation of exploitation by the captains of erudition with little or no benefit to the students, their families or the faculty of the modern University.

The same displacement of goals can be seen when one looks at the actual management of the funds deemed so crucial to the operation of the university should these new hires actually succeed in raising more money. In a revealing analysis of the principal beneficiaries from the management of the large

\footnotetext{
${ }^{5}$ Details concerning the manner in which search firms are used and operate are receiving greater attention now that the cost of higher education is an issue in the 2016 Presidential election campaign. See: Krantz 2015.
} 
endowments, all of which are exempt from corporate income tax on the grounds that universities are primarily responsible for the "advancement and dissemination of knowledge", it appears that private equity fund managers, hired by the universities to manage their endowments, received far more than the money allocated to support tuition assistance, fellowships and prizes. This was true of Harvard, the University of Texas, Stanford and Princeton, all of which had large endowments, as well as Yale. In this last case, Yale paid $\$ 480$ million to its private equity fund managers as opposed to $\$ 170$ million used to directly support students (Fleischer 2015). It may be argued that some of the rest of the endowment benefitted students in an indirect manner by improving the facilities and services of the university but whether this justifies the extraordinary compensation paid to the fund-managers remains a highly controversial issue at a time of the relentless rise in the costs of higher education. Overall, it would seem that, in the contemporary academic world, Veblen's "sturdy beggars" are alive and well.

\section{Marginality, Creativity and Globalization}

Veblen's whole life was a continuous demonstration of how to think outside the box. The conventional narrative, following Dorfman's (1934) influential study, was to relate this to his personal background. The son of a large immigrant family, migrants from the Norwegian countryside living in isolated rural communities in Wisconsin and Minnesota, and only becoming really fluent in English, so it was claimed, after his time as an undergraduate at Carleton College, Veblen lived a type of marginality that was reflected in his somewhat anarchic life style. Later social scientists (Galbraith 1973, Tilman 1992, Edgell 1996) have challenged this portrait and suggested that Veblen's "marginality" was as much a result of his chosen life style as from the difficulties imposed on him by social constraints. As Edgell neatly sums up the situation: "The main lesson from this history of ideas saga is not that Dorfman blazed a false trail, but that so many others followed it uncritically. In other words, a regular dose of Veblenian skepticism is essential to intellectual health." (Edgell 1996: 638). ${ }^{6}$ After completing his doctoral degree and then taking a seven-year, post-doctoral "retreat and rustification" on the family farm -- what looks suspiciously like a family-subsidized, MacArthur genius award if ever there was one! - doesn't suggest the poverty and struggle usually associated with the concept of marginality. It is true that both Simmel and Weber, for entirely different reasons, spent large periods of their lives without an academic income, but while the former might indeed fit the image of "the stranger", due to his Jewish background in Germany at this time, the latter was

\footnotetext{
${ }^{6}$ A criticism of Alice Goffman's highly-praised ethnography, On the Run (2014) follows a similar line of argument. It is not so much that a young researcher - despite her famous name may have failed to be scrupulously accurate in her account of inner city life, but that all the distinguished scholars, referees and a leading academic publisher did not appear to flag any problems with the work (Campos 2015).
} 
clearly afflicted by another more personal set of problems. Both, however, had private incomes that permitted their atypical life styles. If we separate the concept of marginality into two categories: the one "marginality by choice" and the other "marginality by circumstance", the overwhelming evidence is that Veblen belongs to the former. How this might have influenced his insight and understanding of such a social condition remains less clear.

One of the best illustrations of his perspective towards this situation was his well- known essay On the Intellectual Pre-eminence of Jews in Modern Europe, first published in the Political Science Quarterly in March 1919. While pointing to the remarkable creativity of Europe's Jewish population in so many fields he was able to relate this to changes in the structural position of the Jews of Europe once liberated from the confines of the ghettoes and the Pale of Settlement. Moreover, Veblen stressed the advantages of "hybridity" for generating a "skeptical frame of mind" which facilitates release from the "dead hand of conventional finality" (1919: 474-5). He noted the paradox that "none of the peoples of Christendom have been more unremittingly exposed to hybridization, in spite of all the stiff conventional precautions that have been taken to keep the breed pure" (ibid: 470-10). Veblen noted that people of Jewish heritage, given their minority status had made disproportionate contributions to the intellectual life of Western civilization and were particularly "among the vanguard, the pioneers, the uneasy guild of pathfinders and iconoclasts, in science, scholarship, and institutional change and growth." (1919:472). While this analysis focused on the Jewish link between marginality and creativity, he could also be writing about his own outsider circumstances. It resonates with the equally famous essay by Simmel on "The Stranger" ([1908], Levine 1971: 143-149) and both these lines of thought have been adapted to a variety of other groups and situations: the entrepreneurial successes of "middleman minorities" in African and Asian colonial societies to name just one prominent example (Stone and Kirk-Greene 1986).

A further application of the notion of hybridity and creativity can be related to the composition of American society itself: with its diverse mixture of native peoples, slaves from across sub-Saharan Africa, and millions of immigrants arriving from Europe, Latin America, Asia and other parts of the world. While the source of relentless conflicts throughout American history, such a hybrid ancestry has also been the grounds for considerable pride and celebration. It was Israel Zangwill's play The Melting Pot (1908) that represented a positive perspective on American diversity at a time of massive migration flows from Eastern and Southern Europe. It also promoted the idea that hybridity rather than some alleged belief in purity of origins was a strength rather than a weakness. The same theme was to be echoed in the second half of the twentieth century with the publication of John F. Kennedy's book, A Nation of Immigrants (1964), which also stressed the beneficial role of America's mixed heritage. To some degree such ideas could be used to support the theme of American Exceptionalism, although this formulation is less common than one of ethnocentric nationalism. Furthermore, in a manner that would have amused Veblen's satirical viewpoint, each generation of immigrants often turn 
out as they assimilate into the mainstream society to become some of the most vocal critics of successive waves of newcomers. ${ }^{7}$

\section{Nationalism, War and Peace}

Veblen saw the rising salience of warfare and other conflicts in the early years of the twentieth century to be closely linked to the deficiencies of the price system. As Raymond Aron noted "only Thorstein Veblen opens a new chapter by reviving the similarity between the spirit of commerce and the spirit of war" (1966: 250). Despite his sympathy for certain aspects of Marxism, if not such core concepts as the labour theory of value or the claim that history was moving inexorably towards revolution and an egalitarian and cooperative future, his analysis of nationalism recognized that the proletariat in one society could easily be mobilized to fight their fellow workers in another society. The strength of nationalism to trump socialist solidarity was demonstrated at the outbreak of the First World War when workers of the world did unite, but only to fight each other. American intervention in World War 1 had, according to Veblen, "saved the war system" in which "the common man pays the cost and swells with pride" (1919b: 137).

Given the prominence of war in twentieth century Europe, not to mention the violent legacy of imperialism and slavery in the earlier centuries (Stone and Rizova 2014), it is indeed remarkable how much of this phenomenon was ignored by the founding figures of classical sociology. After all, both Durkheim and Weber would enlist for military service in France and Germany, on opposite sides of the conflict, after the outbreak of hostilities in the First World War. And while Marx died in 1883, more than three decades before the conflict began, most of his followers firmly believed that the working classes of Europe would never rush into the trenches to fight and kill their fellow proletarians. Thus, either by the result of neglect or based on faulty analysis, three of the most influential social thinkers in Europe completely failed to comprehend the importance and the dynamics of what was to be one of the fundamental forces shaping modern society. Veblen, on this issue at least, had a much more acute understanding of these matters that should raise our appreciation of his contribution to understanding this key factor in

\footnotetext{
${ }^{7}$ Donald Trump, a third generation American and son of a German-American father and Scottish-immigrant mother, is only a recent example of later generation immigrants appearing to turn against contemporary immigrants. His notorious stereotype of Mexican migrants as "drug dealers and rapists" during the presidential election campaign in June 2015, and advocating the construction of an ever larger wall along the southern border of the USA. This is by no means an exclusively American phenomenon, as research has noted how rapidly such "immigrant societies" as Ireland and Italy, long the source of millions of transatlantic migrants in the $19^{\text {th }}$ and early $20^{\text {th }}$ centuries, quickly adopted the rhetoric and actions used against their fellow countrymen, once they became magnets attracting immigrants in the 1990s. (see: O’Dowd 2005, Blair 2001)
} 
contemporary life, as warfare of various types has continued to plague humanity.

This failure of the classical tradition to give adequate recognition to warfare, let alone anticipate the horrors of genocide, often linked to wartime conflicts, has slowly been acknowledged in mainstream sociological debates (Edgell and Townshend 1992, Joas 1999, Tiryakian 1999). Over the past few decades, the inescapable reality of war and what it can do to all those involved in such struggles has slowly gained the attention of mainstream sociologists. Discussions of the "dark side" of democracy (Mann 2005) and the continuation of the debates about the complex reality of modernity, as social scientists have grappled with the horrifying legacy of the Holocaust, Hiroshima and other examples of technological "progress" being used for diabolical ends, have exposed the blind spots in the sociological tradition. It is on these issues that Veblen's often unusual stress on factors underplayed by the mainstream of the discipline provide particular benefits.

Subsequent observers of the interplay between warfare and economic advantage -- not so much looting and the spoils of war, as the lucrative armaments industries and their influence in provoking and prolonging interstate conflicts -- have come to rather similar conclusions. It was President Eisenhower who coined the term "military-industrial complex" to describe the powerful and closely networked relationships between political leaders, industrialists and the Pentagon. Such a mutually supportive relationship continued on beyond the era of the Cold War and into the twenty first century's "War on Terrorism". The prominent influence of Vice-President Dick Cheney's advocacy in support of the Second Iraq War and his former position as CEO of Halliburton, one of the largest arms suppliers in the country, has led to claims that non-government corporations made billions of dollars in non-bid contracts to supply military equipment for the campaign (Fifield 2013). None of this would have surprised Veblen given his earlier views on the linkage between the "maintenance of the price system" (capitalism) and the "continuing support for national integrity" (nationalism).

That capitalism, far from being the guarantor of international collaboration and peaceful coexistence, might also be one of the key beneficiaries of such conflicts again points to the limitations of neo-classical economic theories. Neither would "socialism" necessarily provide an alternative panacea. Veblen's focus on the diverse functions of warfare reveals just how complex ideas of patriotism, and the need to demonstrate them at particular moments in time, are also at work alongside fairly clear cut economic and political incentives for pursuing such policies. As Andrew Bacevich (2005, 2010), and other critics of recent wars in the Middle East, have argued the advantages of such foreign policy adventures are unclear, the outcomes rarely what their advocates wished, and the cost in terms of lives and treasure enormous. And yet the continuation of such a strategy seems to be bi-partisan in nature with little prospect of an end in sight. The longer term consequences would seem to confirm Veblen's assessment: "whatever may be the nominal balance of profit and loss in the way of what is called the "fortunes of war," the net 
consequences will be much the same; and these consequences cannot but be of the nature of retardation to Western civilization in those respects that mark it as Western and modern" (Veblen 1915: 104).

\section{Conclusion}

When assessing the overall utility of Veblen's work a century after his major books were written, what is fascinating to observe is the contemporary relevance of so many of his key insights. Few sociologists today would accept many of the assumptions underlying some of Veblen's basic analysis. His rather crude attempt to divide up history into simple evolutionary stages: the matriarchal Age of Savagery being followed by the male-dominant Age of Barbarism; the dichotomous division between the positive "instinct for workmanship" and the negative "predatory instinct", as if human motivation could be realistically reduced to two such elemental forces; and his somewhat optimistic view about the impact of technology on human life. With the benefit of hindsight, we can easily modify or dismiss these views. What, however, is remarkable are the potent ideas that can be derived from reading his works as if they had been aimed at American society today.

While we have not discussed the possible implications of Veblen's ideas for such important contemporary issues as environmentalism or feminism, this does not imply that his perspective cannot be employed to shed light on important aspects of the green and gender revolutions of the past few decades (Mitchell 2001, Edgell 1996: 635, 2001: 156). His focus on consumption provides a clear message for the "sustainability" focus of the movements seeking to preserve the environment from wasteful exploitation and global warming. Although his private life does not immediately suggest a great respect for women, a more nuanced reading of his writings could well be seen as attacking traditional patriarchal beliefs and institutions that have stood in the way of greater liberation for women in American and other societies. In many ways, he is a more credible person to be given such accolades than either Marx or Tocqueville, both of whom have received such unexpected (and probably undeserved) credit for these qualities among some recent scholars (Stone and Hou 2010).

No one can discuss consumption without some reference to his ideas of status seeking and while not everyone would agree on the exact nature of purchasing goods for non-utilitarian purposes, few can analyze fashion without considering Veblen's classic writings. It is true that the dynamics of the contemporary fashion industry is no longer guided by the upper classes leading to a trickle down consumption chain in quite the manner Veblen described (Mears 2011: 31, 126, Swartz 1997: 164, Trigg 2001); but the importance of buying goods to enhance one's status remains a fundamental insight into a range of otherwise hard to explain human behaviors. Cosmetic surgery, tanning booths, skin lightening products and many other extremely lucrative businesses are linked to the idea of "invidious comparisons" rather than a rational 
assessment of their utility or even their effectiveness. The symbolic importance of purchasing designer (or even fake copies of) handbags by the Chinese new middle classes is another form of consumption that resonates with Veblen's earlier writings (Zhang 2015).

When it comes to understanding the processes by which American society can generate enormous wealth at the same time as increasing inequality, Veblen's development of a strand of Marxist writings, carefully modified to avoid the dogmatic elements of the doctrine, provides another fascinating convergence between the economic history of the 1920s with that of the second decades of the twenty first century. His focus on the dysfunctional nature of finance capitalism and the divergence between the interests of the wider society and the pecuniary interests of speculative banking could have been written in either era. As John Diggins captured Veblen's attack on the extravagance and wealth of the robber barons, many of them living in mansions in New York, "It seemed like the Medici's had come to Manhattan" (1978:6). Diggins goes on to note how Veblen was able to "contradict flatly almost every premise and assumption upon which the ideology of capitalism rested" (ibid: 13), concluding that "if competition is the guillotine of capitalism, the credit system is its modern gas chamber." (ibid: 22) After the collapse of 2008, most reasonable observers would accept that he had a point, and he might not have been totally surprised how the bankers walked away unscathed from the financial chaos they have created, while the working and middle classes were left to pay the price of their unregulated speculation. ${ }^{8}$ The ironic paradox, "socialism for the rich; capitalism for the poor", is one that Veblen would have truly appreciated.

\section{Acknowledgements}

We would like to thank participants at the ATINER Conference in Athens during May $4^{\text {th }}-6^{\text {th }}, 2015$ for valuable comments on an earlier version of this paper, and David Swartz at Boston University and the two anonymous referees from the AJSS for their helpful suggestions.

\section{References}

Aron R (1966) Peace and War: A Theory of International Relations. New York: Doubleday.

Bacevich A (2005) The New American Militarism: How Americans are seduced by War. New York: Oxford University Press.

\footnotetext{
${ }^{8}$ An interesting variant on the speculative activities of Wall Street banks was the reported case of Goldman Sachs selling off what it knew at the time to be worthless assets to its own clients. These credit default swaps were used to hedge against the collapse of the housing market that the bank understood would be inevitable. Notions of "conflicts of interest", "due diligence" and other measures supposedly designed to maintain protection against such activities were ignored with impunity (Gordon 2009).
} 
Bacevich A (2010) Washington Rules: America's Path to Permanent War. New York: Macmillan.

Berle A, Means G (1932) The Modern Corporation and Private Property. New York: The Macmillan Co.

Blair G (2001) The Trumps: Three Generations that Built an Empire. New York: Simon and Schuster.

Campos P (2015, September 4) Alice Goffman's Implausible Ethnography. The Chronicle Review, B7-B12.

Diggins JP (1978) The Bard of Savagery: Thorstein Veblen and Modern Social Theory. New York: The Seabury Press.

Dorfman J (1934) Thorstein Veblen and His America. New York: Viking.

Economic Policy Institute (2014) Wages, Income and Wealth. Washington D.C.

Edgell S (2001) Veblen in Perspective: His Life and Thought. (2001) New York: M.E. Sharpe.

Edgell S (1996) Rescuing Veblen from Valhalla: A Deconstruction and Reconstruction of a Sociological Legend. British Journal of Sociology 47: 627642.

Edgell S, Townshend J (1992) John Hobson, Thorstein Veblen and the Phenomenon of Imperialism: Finance Capital, Patriotism and War. American Journal of Economics and Sociology 51: 401-420.

Erwin A, Wood M (2014) The One Percent at State U: How Public University Presidents Profit from Rising Student Debt and Low Wage Faculty Labor. Washington D.C.: Institute for Policy Studies. Retrieved from bit.ly/1Ds4WTL.

Erwin A, Wood M (2014) The One Percent at State U: How Public University Presidents Profit from Rising Student Debt and Low Wage Faculty Labor. Washington D.C.: Institute for Policy Studies. Retrieved from bit.ly/1Ds4WTL.

Federal Reserve Bank of Boston (2015) The Color of Wealth in Boston. A Joint Publication with Duke University and the New School. Authors: Ana Munoz, Marlene Kim, Mariko Chang, Regine Jackson, Darrick Hamilton and William Darity.

Fifield A (2013) Contractors reap $\$ 138$ bn from Iraq War. Financial Times March $18^{\text {th }}$

Fleischer V (2015, August 19) Stop Colleges from Hoarding Cash. The New York Times.

Fourcade M (2009) Economists and Societies: Discipline and Profession in the United States, Britain \& France, 1890s to 1990s. Princeton: Princeton University Press.

Galbraith JK (1973) A New Theory of Thorstein Veblen. American Heritage 24: 3240.

Ginsberg B (2011) The Fall of the Faculty: The Rise of the All-Administrative University and why it Matters. Oxford: Oxford University Press.

Goffman A (2014) On the Run: Fugitive Life in an American City. Chicago: Chicago University Press.

Gordon G (2009, November 1) Goldman Sachs: Low Road to High Finance. McClatchy Newspapers.

Granovetter M (1973) The Strength of Weak Ties. American Journal of Sociology 78(6): 1360-1380.

Joas H (1999) The Modernity of War: Modernization Theory and the Problem of Violence. International Sociology 14(4): 457-472.

Kennedy JF. (1964) A Nation of Immigrants. New York: Harper-Collins.

Kranish M (2015, March 29) Divided Nation. Boston Globe.

Krantz L (2015, August 10) College Searches Proving Costly. Boston Globe. 
Levine D (1971) George Simmel on Individuality and Social Forms. Chicago: University of Chicago Press.

Lewis M (2014) Flash Boys: A Wall Street Revolt. New York: Norton

Mann M (2005) The Dark Side of Democracy: Explaining Ethnic Cleansing. New York: Cambridge University Press.

Mears A (2011) Pricing Beauty: The Making of a Fashion Model. Berkeley \& Los Angeles: University of California Press.

Mennell S (2007) The American Civilizing Process. Cambridge: Polity Press.

Mitchell R (2001) Thorstein Veblen: Pioneer in Environmental Sociology. Organization and Environment 14(4):389-408.

O'Dowd AH (2005) Establishing Boundaries: A Comparative Analysis of Immigrants as Outsiders in Ireland and Italy. PhD Diss. University College, Dublin.

Oliver M, Shapiro T (1995) Black Wealth, White Wealth: A New Perspective on Racial Inequality. New York: Routledge.

Piketty T (2014) Capital in the Twenty-First Century. Cambridge, MA: Harvard University Press.

Putnam R (2015) Our Kids: the American Dream in Crisis. New York: Simon and Schuster.

Rhoads, R (2015) MOOCs, High Technology, and Higher Learning. Baltimore: Johns Hopkins University Press.

Rizova P (2007) The Secret of Success: The Double Helix of Formal and Informal Structures in an $R \&$ D Laboratory. Stanford, CA: Stanford University Press.

Schworm P (2014, December 8) Pay climbs for colleges' presidents. Boston Globe.

Shapiro T (2005) The Hidden Cost of being African American: How Wealth Perpetuates Inequality. New York: Oxford University Press.

Simmel G (1908) The Stranger [Der Fremde]. Soziologie, 685-691. Munich: Duncker \& Humblot.

Smith A (2010; [1759]) The Theory of Moral Sentiments. London: Penguin Classics.

Strauss, V (2014, December 8) The surprising top 10 highest paid private college presidents. Boston Globe.

Stone J, Rizova P (2014) Racial Conflict in Global Society. Cambridge: Polity Press.

Stone J, Hou X (2010) Alexis de Tocqueville in the twenty-first century: plus ça change, plus c'est la mểme chose?. Theory and Society 39: 109-118.

Stone J, Kirke-Greene A (eds) (1986) Ethnicity, Empire and Race Relations. London, Routledge.

Swartz D (1997) Culture and Power: The Sociology of Pierre Bourdieu. Chicago: Chicago University Press.

Tilman R (1992) Thorstein Veblen and his Critics, 1891-1963. Princeton: Princeton University Press.

Tiryakian E (1999) War the Covered Side of Modernity. International Sociology 14(4): 473-489.

Trigg A (2001) Veblen, Bourdieu, and Conspicuous Consumption. Journal of Economic Issues 35(1): 99-115.

Veblen T (1953) [1899] The Theory of the Leisure Class. New York: Viking Press.

Veblen T (1966) [1915] Imperial Germany and the Industrial Revolution. Ann Arbor: University of Michigan Press.

Veblen T (1965) [1918] The Higher Learning in America: A Memorandum on the Conduct of Universities by Business Men. New York: Augustus M. Kelley.

Veblen T (1919) On the Intellectual Pre-eminence of the Jews in Modern Europe. Political Science Quarterly 34: 33-42. 
Veblen T (1919b) The Vested Interests and The Common Man: The Modern Point of View and the New Order. New York: Augustus M. Kelley.

Veblen T (1964) [1923] Absentee Ownership and Business Enterprise in Recent Times: The Case of America. New York: Augustus M. Kelley.

Woolhouse M, Newsham J (2015, March 27) On Matters of Race and Wealth: Boston Fed finds Stunning Chasm. Boston Globe.

Zangwill I (1908) The Melting Pot. New York: Macmillan.

Zhang W (2015, October 18) No Cultural Revolution: Continuity and Change in Consumption Patterns in Contemporary China. Journal of Consumer Culture. doi:10.1177/1469540515611202 
Vol. 3, No. 4 Stone et al.: Veblen in Twenty-First Century America... 